\title{
29-72 aylık çocukların olumsuz ve prososyal yalan söyleme davranışlarının incelenmesi
}

\section{Investigation of antisocial and prosocial lie telling behaviors of 29-72 month-old children}

\author{
Muhammed Şükrü Aydın ${ }^{1}$
}

\begin{abstract}
Makale Geçmişi
Geliş : 27 Subat 2020

Düzeltme : 29 Eylül 2020

Kabul : 10 Subat 2021
\end{abstract}

\section{Makale Türü}

Arastırma Makalesi

\section{Article History}

Received : 27 February 2020

Revised : 29 September 2020

Accepted : 10 February 2021

\section{Article Type}

Research Article

\begin{abstract}
Öz: Yalan söyleme davranışları konusunda yapılan çalışmalar çocukların genellikle üç yaşından itibaren basit yalanlar söyleyebildiklerini göstermektedir. Ancak ülkemizde bu konuda çalışmaların yapılmamış olması, Türkiye'deki çocukların yalan söyleme becerileri konusunda yorum yapılmasını zorlaştırmaktadır. Bu nedenle, mevcut çalışmada ülkemizdeki okul öncesi dönem çocuklarının olumsuz ve prososyal yalan söyleme davranışları incelenmiștir. Araștırma nicel araștırma yöntemlerinden betimsel yöntem ile yürütülmüş, yapılandırılmış doğrudan gözlemle davranışlar kaydedilmiştir. Çalışmaya yaşları 29-72 ay $($ Ortay $=51,94)$ arasında değişen 62'si k1z, 62'si erkek olmak üzere toplam 124 çocuk katılmıştır. Katılımcıların olumsuz yalan söyleme davranışlarını değerlendirmek için cazibeye karşı koyma görevi, prososyal yalan söyleme davranışlarını değerlendirmek için de hayal kırıklı̆̆ına uğratan hediye görevi kullanılmıştır. Analizler sonucunda, olumsuz yalan söyleme konusunda büyük yaş çocuklarının anlamlı olarak daha başarılı oldukları; prososyal yalanların ise yaşa göre anlamlı farklılık göstermediği bulunmuştur. Bulgular büyük yaş çocuklarının gelişmekte olan bilişsel becerileri ve yaşla birlikte daha çok etkilendikleri sosyalleşme süreçleri kapsamında tartışılmıştır. Sonuçlar, Türkiye'de henüz emekleme aşamasında olan küçük yaş çocuklarının yalan söyleme davranıșları konusunda öncü bilgiler sağlaması bakımından önem taşımaktadır.
\end{abstract}

Anahtar Kelimeler: Yalan Söyleme, Kandırma, Olumsuz Yalan, Prososyal Yalan, Beyaz Yalan.

Abstract: Researcher has demonstrated that children can typically tell simple lies from the age of three. However, in Turkey, because nothing is known about children's lies, it makes stronger to comment on children's lie telling abilities. Therefore, the present study examined antisocial and prosocial lie telling behaviors of preschool children in Turkey. The research was conducted using the descriptive method, one of the quantitative research methods, and behaviors were recorded through structured direct observation. A total of 124 children (62 girls and 62 boys) aged between 29 and 72 months (Mage = 51.94 months) participated in the study. The participants were assessed using the temptation resistance paradigm to evaluate their antisocial lies and using a disappointing gift task for prosocial lies. As a result of the analysis, it was found that older children were more successful in terms of antisocial lie telling; however, prosocial lie telling did not differ according to age. These results are discussed in terms of developing cognitive abilities of older children and socialization processes, in which they are more effective for children getting older. The results are important in terms of providing pioneering information on the topic of lying behaviors in young children, who are still in their infancy in Turkey.

Keywords: Lie Telling, Deception, Antisocial Lie, Prosocial Lie, White Lie. 


\section{SUMMARY}

\section{Introduction}

Although the literature has provided different definitions of lies, it is thought that the intention of the lie is important. When evaluated from this point of view, it can be said that a lie can be divided into "prosocial" and "antisocial" types (see Aydin, 2020). In recent years, most of the studies emphasized that lying and deception is a developmental phenomenon; therefore, studies on the development of the lying behavior in children are critical (see Talwar and Crossman, 2011). It is noteworthy that both antisocial and prosocial lies are told mostly with children who grow up in western cultures. Although there are many studies on when children from different countries such as America and Canada begin to tell different types of lies, there are almost no findings from other countries. It is not yet known when lie telling behaviors start in a country, such as Turkey, that is not exactly affected by the western and/or eastern culture. Thus, it may be beneficial for one to study different types of lies in a different culture. Accordingly, the frequency of antisocial and prosocial lies of children aged 2-5 years were investigated in this study. It was also examined whether there is a significant difference between ages in different types of lies.

\section{Method}

A total of 124 children (62 girls and 62 boys) aged between 29 and 72 months participated in this study. The participants were assessed using the temptation resistance paradigm to evaluate their antisocial lies and using a disappointing gift task for prosocial lies. The data were collected from five different preschool education institutions in Istanbul. After Ethics Committee's approval was obtained, informed consent forms were sent to the parents of the children through schools.

\section{Results}

The findings indicate that only one of the 2-year-old children (6.3\%) told antisocial lie, whereas $25 \%$ of 2 year-old children told prosocial lie. For 3-year-old children, it was found that $24.1 \%$ of the children told antisocial lies, and $41.4 \%$ of them told prosocial lies and could give reasonable answers. It was observed that $43 \%$ of 4 -year-old children could tell antisocial lies, and $28.6 \%$ of them could tell prosocial lies. Finally, it was found that $43.2 \%$ of 5 -year-old children could tell antisocial lies, and $51.4 \%$ of them lie prosocially. A chi-squared analysis was performed to test whether there is a significant difference between the ages and antisocial and prosocial lies of children. It was found that antisocial lies differ significantly according to age $\left[\chi^{2}(6)=25.12, \mathrm{p}<0.01\right]$, however, there were no significant differences in prosocial lies according to age $\left[\chi^{2}(6)=9.2, \mathrm{p}>0.05\right]$.

\section{Conclusion and Discussion}

When the results were first evaluated in terms of antisocial lies, it was found that a 34-month-old child in the present study acquired the ability to lie on a subject that required him to hide the rule violation, although it was observed that most of the 2-year-old children confessed when they turned their backs or waited. This 
situation is consistent in many studies conducted abroad (e.g., Nagar, Williams and Talwar, 2019; O'Connor and Evans, 2018). Many researchers (see Ekman, 2016) stated that children started to tell simple lies (such as covering up their mistakes, to avoid punishment) from 30 months. This study supports previous studies through the finding that the situation is similar in Turkey.

Considering prosocial lies, it was concluded that children had this ability at an early age, compared to the antisocial lie telling ability. Although the antisocial lie telling behavior was observed in a youngest 34-monthold child, it was observed that prosocial lies occurred in 32-33-month-old children, and this rate was $25 \%$ in 2-year-old children. When a prosocial lie is evaluated against the finding that antisocial lies increase with age, it is noteworthy that there is no linear increase of prosocial lie telling with age and that older children use correct expressions, such as "I do not like the gift," in this situation which requires kindness. In fact, this situation is not fully correlated with the results from other studies. It can be said that this is consistent with some research findings that prosocial lies occur around the age of 3 (e.g., Talwar, Lavoie and Crosssman, 2019) and that there are no age differences in prosocial lies (Williams, Moore, Crossman \& Talwar, 2016); however, results that are especially from communities, such as America and Canada, indicate that antisocial lies are seen earlier than prosocial lies are different from those in the current study (see Talwar and Crossman, 2011).

In the current study, it was found that prosocial lies did not increase linearly with age. One of the possible explanations that can be made on this subject is that parents who have the most impact on children's early development may also affect their children's prosocial lies. It is known in Turkey that there is a common belief that in situations and events that require kindness, white lies can be said in the folk language or that it is not appropriate to tell the truth every time. It can be thought that children exposed to such thoughts also act accordingly. In the later years of the preschool period, in parallel with the developing language, cognitive, and social development, it may be suggested that children, influenced by their parents as well as teachers, take supportive actions to easily share their thoughts and desires and that children may give more importance to their own wishes over the school period. It is known that children socialize through their parents, peers, teachers, and other cultural factors, and these affect children in various ways. Allowing or punishing children for their lie telling behavior can vary in different cultures in different contexts and can affect children's lies and judgments in a variety of ways. Therefore, the finding that the prosocial lies occurred earlier than antisocial lies in this study can also be explained by social and cultural factors. 


\section{GİRIŞ}

Yalan söyleme davranışı, gelişim psikolojisi alanında uzun süredir ele alınan konulardan biridir. Birçok araştırma sonucunda, çocukların gelişimlerinin doğası gereği 3 yaş civarında hatalarını ört bas etmek ve ödül elde etmek için sistematik ve profesyonel olmayan basit yalanlar söyleyebildikleri görülmektedir. Ancak ülkemizde çocukların ne zaman yalan söylemeye başladıkları, yaşla birlikte durumun değişip değişmediği gibi konular belirsizliğini korumaktadır. Bu nedenle mevcut çalışmada, Türkiye'de yaşayan okul öncesi dönemdeki çocukların yalan söyleme davranışlarının incelenmesi hedeflenmiştir.

Erken çocukluk döneminde yalan söyleme davranışlarının gelişimine geçmeden önce yalanın tanımı ve türlerine değinmek yerinde olacaktır. Yalan genel olarak "gerçek olmayan ifade" şeklinde düşünülebilir ancak bu kavram göründüğü kadar sade değildir. Yalanın birçok tanımında "niyetlilik" ve "başkalarına yanlış bilgi vermenin” kritik önem taşıdığı görülmektedir. Örneğin, Goffman (1967) yalanı, "bir ya da birkaç kişinin bir olayla ilgili ne olup bittiği konusunda başkalarında yanlış kanılar oluşturma çabaları" şeklinde ifade etmektedir. Lee ve Ross (1997) ise yalanın içerdiği üç bileşeni şu şekilde sıralamıştır: a) ifadenin yanlış olması, b) konuşmacının ifadenin yanlış olduğunu bilmesi, c) konuşmacının karşısındakini niyetli olarak kandırması.

Yalana ilişkin toplumu yozlaştıracağı, sosyal ilişkilerimize zarar vereceği, insanlar arasındaki beraberlik ve uyuma ket vuracağı gibi görüşler genel olarak ağır basmaktadır. Sosyal normlar kandırma ve yalan söylemeye açıkça karşı çıkıyor olmasına rağmen bu tür davranış ve söylemlerin bütün toplumlarda ve toplumun her kesiminde görülmesi mümkündür. İnsanlar her ne kadar karş1 çıkıyor ve kendilerini ahlaklı görüyor olmalarına rağmen, büyük bir çoğunluğu her gün yalana başvurmaktadır (DePaulo, Kashy, Kirkendol, Dwyer ve Epstein, 1996). Bunun nedeni, hem yetişkinlerin hem de çocukların yalanı tek tip olarak kabul etmemeleri olabilir. Çalışmalar, çocuk (Örn., Evans ve Lee, 2013) ve yetişkinlerin (Örn., DePaulo, Ansfield, Kirkendol ve Boden, 2004) kişinin kendi çıkarını korumak amacıyla söylediği yalanları (antisosyal), başkalarının yararı için söylenen yalanlara (prososyal) göre daha olumsuz değerlendirdiklerini göstermektedir.

$\mathrm{Bu}$ durum araştırmacıları, yalanın sonuçları ve söylenmesinin altında yatan nedenleri incelemeye yöneltmiştir. Yalan söyleme davranışları bu perspektiften değerlendirildiğinde yalanın "prososyal" ve "olumsuz" olarak ikiye ayrılabileceği söylenebilir (bkz. Aydın, 2020). Sosyal yönden kabul edilebilir olan yalanlara "başkası yönelimli”, “ince düşünceli”, "beyaz” ve "özgeci” yalan gibi isimler veriliyor olsa da bunların "prososyal yalan” başlı̆̆1 altında toplanması uygun görülmektedir. Çoğunlukla kibarlık ve nezaket içeren prososyal yalanlar, ilişkinin istikrarını sürdürebilmek, bir 
başkasının iyi oluşuna hizmet etmek, üzüntüsünü gidermek ve incitmemek gibi farklı amaçlarla ortaya çıkabilir. Yalanın hem günlük hayatta karşılaşılan hem de alan yazında en çok incelenen türü olan olumsuz yalanlar ise kişinin kendi çıkarına hizmet eden yalanlardır. Bazı durumlarda başkasına zarar verme amacı taşıyan ve karşılıklı iletişimi, güveni zedeleyen bu tür yalanlar, cezadan kaçınma, bir yanlışı̈ ört bas etme ve kendini koruma gibi güdülerle söylenebilmektedir.

Son yıllarda yapılan araştırmalar, yalan ve kandırma davranışını anlayabilmek için bu tür davranışların nasıl başladığını ve gelişim gösterdiğini incelemeye doğru kaymıştır. Bu doğrultuda araştırmaların birçoğunda, yalan söyleme ve kandırmanın gelişimsel bir fenomen olduğu ve dolayısıyla çocuklarda yalan söyleme davranışının gelişimi ile ilgili çalışmaların kritik öneme sahip olduğu vurgulamıştır (Bkz. Talwar ve Crossman, 2011).

Çocuklar konuşmaya başladıklarında sözlü yalanları da artık tespit edilebilir hale geldiğinden ne zaman ve hangi nedenlerle yalan söylediklerine ilişkin tespitlerin yapılması kolaylaşmıştır. Talwar ve Crossman'ın (2011) antisosyal yalan olarak tanımladığı kendi çıkarına hizmet eden olumsuz yalanlar, benlik anlayışı gelişiminin yanı sıra zihinsel durumlara ilişkin basit bir anlayıştan sonra (örn., Annem yanlış bir şey yaptığımı bildiği takdirde kızacaktır) ortaya çıkmaktadır. Burada hem çocuğun kendisinin yanlış bir şey yaptığına dair anlayışı hem de kendi eyleminin başkaları tarafindan bilinemeyeceği gibi iki temel beceri önem arz etmektedir. Bu araştırmacılar, benlik anlayışının 1524 aylar arasında (Lewis, Sullivan, Stanger ve Weiss, 1989); basit zihin kuramı anlayışının 2 yaş civarında yerleşmeye başladığ1 (Moll ve Tomasello, 2007) yönündeki açıklamalarla görüşlerini desteklemeye çalışmışlardır. Ekman (2016) ise 2-3 yaş arasındaki çocuklanın yalan söyleme konusunda çok başarılı olamadıklarını ancak yalan söylediklerinde ise bunu cezadan kaçınmak ya da kendini korumak amaçlı söylediklerini ifade etmektedir. Bu yaş dönemindeki çocukların yalanları sıradan ve basit olduğu gibi, kendiliğinden itiraf edilme olasılıkları da yüksektir.

Küçük çocukların 2 yaşından itibaren kendi kural ihlallerini gizlemek için basit yalanlar söyleyebildiklerini ortaya koyan bulgular alan yazında mevcuttur (örn., Evans ve Lee, 2013; Talwar ve Lee, 2008). Kural ihlalini saklama şeklindeki antisosyal yalanlar, çocuğun araştırmacının olmadığı bir ortamda oyuncağa dokunmaması ya da bakmaması gerektiğinin söylendiği “cazibeye karşı koyma" görevi ile test edilmektedir (örn., Lewis ve diğerleri, 1989; Talwar ve Lee, 2002a). Bu görevde çocuklarla bir tahmin oyunu oynanır ve üç doğru tahminde bulundukları takdirde kendilerine ödül verileceği söylenir. Çocuklardan yüzü duvara dönük olacak şekilde oturmaları istendikten sonra araştırmacı bir oyuncak çıkarır ve çıkardığı sesten çocukların oyuncağın ne olduğunu tahmin etmeleri istenir. Tahmin edilmesi kolay olan birkaç denemeden sonra (örn. 
ağlayan bebek sesi, polis arabası sireni), çocuğu zorlayan test aşamasına geçilir. Araştırmacı test aşamasında, normalde o sesi çıkarmayacak pelüş bir oyuncak seçer ancak oyuncaktan müzik kutusundan çıkana benzer bir ses gelmektedir. Çocuklar tahminde bulunmadan önce araştırmacı odadan bir dakikalı̆̆ına ayrılması gerektiğini ve kendisi dışarıdayken çocukların arkalarına bakmamaları gerektiğini söyler. Araştırmacı odadan çıktıktan sonra bütün çocukların arkalarını dönüp baktıkları görülmüştür. Bir dakika sonra araştırmacı kapıya yaklaşarak gürültü çıkarır ve ardından odaya girer. Çocuklar araştırmacıya doğru cevabı verdikten sonra araştırmacı çocuklara arkalarını dönüp bakıp bakmadıklarını sorar. Çalışmanın sonucunda, üç yaşındaki çocukların çoğunun arkalarını döndüklerini ve sonrasında bunu itiraf ettikleri görülmüştür. Dört yaşındaki çocukların büyük çoğunluğunun yalan söyleyebildiği, altı yaşındaki çocukların ise \% $\% 5$ 'inin yalana başvurduğu bulunmuştur.

Çocukların doğal ortamlarında söyledikleri yalanlar ise sadece birkaç çalışmada incelenmiştir. Wilson, Smith ve Ross'un (2003) çalışmasında 3-6 yaş arasındaki 40 çocuğun kandırma sıklıkları evlerinde iki ayrı 90 dakikalık zaman diliminde gözlemlenmiştir. Gözlemler sonucunda, çocukların yalanlarının yaşla birlikte arttığı ve en çok görülen yalan söyleme nedenlerinin sorumluluktan kaçınma, kontrol elde etme ve kardeşine suçlamada bulunma olduğu bulunmuştur. Ayrıca 3 yaşındaki çocukların \%65'inin, 4 yaşındaki çocukların ise \%94'ünün en az bir kere yalan söylediği sonucuna ulaşılmıştır. Bir diğer çalışmada Newton, Reddy ve Bull (2000) 3-4 yaşında çocuğa sahip olan 24 anneden çocuklanın doğal ortamlarında söyledikleri yalanları not etmelerini istemişlerdir. Bu çalışmanın sonuçları da bütün çocukların bir işten kaçınmak için, bir kazanç elde etmek için yalan söyleme becerisine sahip olduklarını göstermiştir.

Çocuklarda olumsuz yalanları ele alan araştırmaların sayısının belli bir doygunluğa ulaştığı söylenebilir ancak prososyal yalanların ne zaman görülmeye başlandığı, nasıl bir gelişim gösterdiğine ilişkin araştırmalar oldukça sınırlıdır. Bu konudaki öncü çalışmalardan biri (Gnepp ve Hess, 1986), nezaket gerektiren durumlarda 6 yaşındaki çocukların prososyal yalan söyleyebildiklerini göstermiştir. Daha yakın zamanda Talwar ve Lee (2002b) tarafindan yürütülen çalışmanın sonucunda ise 3 ile 7 yaş arasındaki çocukların \%89'unun prososyal yalan söyleyebildiklerini bulmuşlardır. Bulguların yaşa göre farklılık göstermediği de dikkate alındığında, 3 yaşındaki çocukların prososyal yalan söyleme becerisini kazandıkları ifade edilmiştir. Prososyal yalan konusunda bir diğer çalışma alanı ise çocukların bu tür yalanları kullanımı sırasında kendilerinde ne gibi değişiklikler meydana geldiğini ve aynı zamanda duygu ve yüz ifadelerinin nasıl değiştiğini incelemektedir. Saarni (1984) tarafindan istenmeyen hediye görevinin kullanılmış olduğu bir çalışmada, beşinci sınıf öğrencilerinin yüz ifadelerini maskelemeyi başardıkları bulunmuştur. Cole 
(1986) benzer bir görevle okul öncesi dönem çocukları üzerinde bir çalışma gerçekleştirmiş ve sonucunda 3 ve 4 yaşındaki çocukların da bu beceriyi gösterdikleri sonucuna ulaşmışır. Bu gibi sonuçlar, okul öncesi dönemdeki çocukların nezaket gösterilmesinin beklenildiği ortamlarda gerçek hislerini saklamaları gerektiğinin kavrandığını ortaya koymaktadır.

Literatür taraması yapıldığında, hem olumsuz yalanların hem de prososyal yalanların daha çok batılı kültürlerde yetişen çocuklarla yürütüldüğg̈ göze çarpmaktadır. Amerika, Kanada gibi ülkelerden seçilen çocukların farklı türde yalanları ne zaman söylemeye başladıklarına ilişkin birçok çalışma mevcutken, farklı ülkelerden gelen bulgular yok denecek kadar azdır. Prososyal ve olumsuz yalanların Türkiye gibi tam olarak batı ve doğu kültürü etkisinde sayılamayacak bir ülkede ne zaman görülmeye başlandığı meselesi ise henüz bilinmemektedir. Yazarın bilgisine göre, ülkemizde okul öncesi dönem çocuklarıyla sadece bir çalışma gerçekleştirilmiştir. Bu çalışmada da sadece prososyal yalan türü ele alınmış, yaş grubu olarak da 54-66 ay gibi sınırlı bir yaş aralığ1 seçilmiştir (Bkz. Oğuz ve Kara, 2018). Bu durum göz önünde bulundurularak, farklı yalan türlerinin daha küçük yaşlarda ve daha geniş yaş aralığındaki çocuklarla çalışılması hedeflenmiştir. Bu doğrultuda, mevcut betimsel çalışmanın amacı 2, 3, 4 ve 5 yaşındaki çocukların hem olumsuz hem prososyal yalan söyleme davranışlarının incelenmesidir. Çalısmanın bir diğer amacı ise, her iki yalan türü açısından ülkemizdeki okul öncesi dönem çocuklarının yaş grupları arasında anlamlı farklılık olup olmayacağının incelenmesidir.

\section{YÖNTEM}

\section{Araştırma Deseni}

$\mathrm{Bu}$ araştırmada okul öncesi dönem çocuklarının yalan söyleme davranışlarının mevcut değerlendirmesi yapıldığından, araştırma nicel araştırma yöntemlerinden betimsel yöntem ile yürütülmüştür. Uygulamaların doğası gereği gözleme dayalı yöntemlerden yapılandırılmış doğrudan gözlem yöntemi tercih edilmiştir.

\section{Katılımcilar}

Çalışma grubunun oluşturulmasında İstanbul ili Anadolu yakasındaki 14 ilçe arasından kolay ulaşılabilirlik ilkesi göz önüne alınarak Kadıköy, Sancaktepe ve Üsküdar ilçeleri seçilmiştir. Araştırmanın katılımcılarını İstanbul ilinde yer alan özel okul öncesi kurumlarda eğitimine devam eden 2, 3, 4 ve 5 yaşlarındaki (Ort=51.94 ay; Ss=11.83) 62 kı ve 62 erkek olmak üzere toplam 124 çocuk oluşturmaktadır. Çalışmaya katılan çocukların 16’sı (\%12,9) 29-35 ay; 29’u (\%23,4) 36-47 ay; 
42’si $(\% 33,9)$ 48-59 ay; 37’si $(\% 29,8)$ ise 60-72 ay yaşları arasındadır. Çalışma için anaokulu yönetici ve psikologlarına uygulamalar anlatılarak gerekli izinler alınmış, daha sonra katılımcıların ebeveynlerinden çalışmaya katılabilmeleri hususunda onam formlarını doldurmaları istenmiştir. Çalışmaya katılmasına izin verilmeyen çocuklar çalışmaya dâhil edilmeyerek, ebeveynlerinden izin alınan çocuklarla çalışmaya devam edilmiştir.

Tablo 1. Katılımcıların cinsiyet ve yaş dilimlerine göre dağglımı

\begin{tabular}{lccc}
\hline & Kız $(\mathbf{n})$ & Erkek $(\mathbf{n})$ & Toplam $(\mathbf{n})$ \\
\hline 2 yaş (29-35 ay) & 8 & 8 & 16 \\
3 yaş (36-47 ay) & 16 & 13 & 29 \\
$\mathbf{4}$ yaş (48-59 ay) & 26 & 16 & 42 \\
$\mathbf{5}$ yaş (60-72 ay) & 12 & 25 & 40 \\
\hline
\end{tabular}

\section{Veri Toplama Araçları}

\section{Hayal Kınkliğına Ŭgratan Hediye Görevi}

Çocukların prososyal yalan becerisini ölçmek amacıyla Saarni (1984) tarafindan geliştirilen "hayal kırıklığına uğratan hediye” paradigması kullanılmıştır. İlk olarak yardımcı araştırmacı (A2) çocukla birlikte uygulama odasına girdikten sonra çocuğa içerisinde çıkartma, balon, top, oyuncak araba ve sabun olan kutuyu göstererek "oyunumuz bittiğinde bunlardan birini sana vereceğim, şimdi bana en çok beğendiğin ve beğenmediğin şeyi gösterir misin” diye sorarak cevaplar1 not etmiştir. Bu sırada, araştırmacı (A1) uygulama odasında olmadığı için çocukların hangi hediyeyi beğendikleri ve beğenmedikleri konusunda bilgi sahibi değilmiş gibi görünmektedir. Çocukların cevapları kaydedildikten sonra çocuk ve A1 tahmin oyunu şeklinde isim verilen "Cazibeye Karşı Koyma Görevi” oynanmıştır. Bu görevin tamamlanmasının ardından A1 "Benimle vakit geçirdiğin için teşekkür ederim, şimdi senin için seçtiğim bir hediyem var.” Demiş ve sonrasında kutunun içerisinden gözü kapalı bir şekilde oyuncağı seçmiştir. Kutudan seçilen hediye çocuğun beğenmediğini söylediği nesnedir. A1 kötü hediyeyi çocuğa verir ve "hediyeni nasıl buldun" diye sorar. Böylece çocuğa gerçek ve yalan söyleme firsatı sunulur. Çocuk doğru söyleyerek hediyeyi beğenmedim derse " 0 ” puan verilmiştir. Beğendim diyerek yalan söyleyen çocuklar için iki farklı soru daha yöneltilmiştir: "Hediyenin en çok hangi özelliğini beğendin?” ve "hediyenle ne yapmayı düşünüyorsun?” Bu sorulara akla yatkın cevaplar vermeyen (örn., beğendim işte, bilmiyorum vb.) katılımcıların prososyal yalan cevapları "1” puan, makul cevaplar veren (örn., rengini beğendim, ellerimi yıkarım vb.) katılımcıların prososyal yalan cevapları ise 2 puan olarak kodlanmıştır.

\section{Cazibeye Karş1 Koyma Görevi}


Çocukların olumsuz yalan becerilerini ölçmek amacıyla Talwar ve Lee (2002a) tarafından uygulanılan “cazibeye karşı koyma” paradigması kullanılmışıı. Bu görevde çocuklarla bir tahmin oyunu oynanır ve üç doğru tahminde bulundukları takdirde kendilerine ödül verileceği söylenir. Çocuklardan yüzü duvara dönük olacak şekilde oturmaları istendikten sonra A1 çantasından bir oyuncak çıkarır ve çıkardığ1 sesten çocukların oyuncağın ne olduğunu tahmin etmeleri istenir. Tahmin edilmesi kolay olan iki denemeden sonra (1-ağlayan bebek, 2-polis arabası), çocuğu zorlayan test aşamasına geçilir. Test aşamasında ise oyuncak arı seçilmiştir ancak bu oyuncaktan arı vızıldaması yerine müzik kutusundan çıkan sesleri anımsatan bir ses gelmektedir. Çocuklar tahminde bulunmadan önce araştırmacı odadan bir dakikalığına ayrılması gerektiğini ve kendisi dışarıdayken çocukların arkalarına bakmamaları gerektiğini söyler. Bir dakika sonra araştırmacı kapıya yaklaşarak gürültü çıkarır ve ardından odaya girer. Çocuklar araştırmacıya oyuncak tahmini hakkında cevaplarını söyledikten sonra A1 çocuklara arkalarını dönüp dönmediklerini sorar. Arkasını dönüp baktığını ifade eden çocuklara “ 0 ”, arkasını dönmeyip doğru tahminde bulunamayan çocuklara “1”; arkasına dönmediğini söyleyip oyuncak arıyı doğru tahmin eden çocuklara ise “2” puan verilmiştir. Çocukların arkalarını dönüp dönmedikleri cevaplarından anlaşılmaktadır ancak bunlara ek olarak okulların güvenlik kameralarından da yararlanılmıştır.

\section{Veri Toplama Süreci}

Çalışmanın verileri İstanbul'da yer alan 5 farklı okul öncesi eğitim kurumundan toplanmıştır. Araştırmada kullanılacak görevler için İstanbul Üniversitesi Sosyal ve Beşeri Bilimler Etik Kurul Onayı alınmış ardından uygulama yapılacak okulların yöneticileri, psikologları ve öğretmenlere çalışma hakkında bilgilendirme yapılmıştır. Öğretmenler aracılı̆̆ıyla çocukların ebeveynlerine çalışmaya ilişkin bilgilendirici bir yazı ve onam formları gönderilerek; ebeveynlerinin izin verdiği çocuklar ile çalışma yürütülmüştür. Çalışmaya geçmeden önce 1sınma amacıyla araştırmacılar çocukların sınıfına giderek tanışmışlardır. Böylece araştırmacıların yabancılık etkisinin ortadan kaldırılması hedeflenmiştir. Uygulamalar için okul içerisinde araştırmacı ve çocuğun rahatlıkla oynayabileceği sessiz bir oda tercih edilmiştir. Veriler tek bir oturumda toplanmış ve çocuklara sırasıyla prososyal yalan ve olumsuz yalan görevleri uygulanmıştır. İki görevin uygulanması her bir çocuk için yaklaşık 5-10 dakika sürmektedir.

\section{BULGULAR}

Çalışmanın amacı, 2-5 yaş arasındaki çocukların olumsuz ve prososyal yalan söyleme davranışlarının sıklıklarının ve her iki yalan türünde yaşa bağlı anlamlı farklılıkların görülüp görülmediğinin incelenmesiydi. Sonuç çıkarıcı analizlerin verilmesinden önce çocukların olumsuz ve prososyal 
yalan söyleme davranışlarının yaşlara göre dağılımlarına ilişkin hazırlanan betimleyici istatistikler Tablo 2'de verilmiştir.

Tablo 2. Olumsuz ve prososyal yalan söyleyen çocukların yaşlara göre dağglımını gösteren ki-kare tablosu

\begin{tabular}{|c|c|c|c|c|c|c|c|}
\hline & & & lumsuz Yala & & & sosyal Yalan & \\
\hline & $\begin{array}{c}\text { Yaş Grubu / } \\
\text { Cevaplar }\end{array}$ & $\begin{array}{c}\text { Baktığını } \\
\text { İtiraf } \\
\text { Eden }\end{array}$ & $\begin{array}{c}\text { Bakmadığ1 } \\
\text { hakkında } \\
\text { doğru } \\
\text { söyleyen }\end{array}$ & $\begin{array}{c}\text { Yalan } \\
\text { Söyleyen }\end{array}$ & $\begin{array}{c}\text { Yalan } \\
\text { Söylemeyen }\end{array}$ & $\begin{array}{c}\text { Yalan } \\
\text { Söyleyen } \\
\text { (Makul } \\
\text { Cevaplar } \\
\text { Vermeyen) }\end{array}$ & $\begin{array}{c}\text { Yalan } \\
\text { Söyleyen } \\
\text { (Makul } \\
\text { Cevaplar } \\
\text { Veren) }\end{array}$ \\
\hline & n & 10 & 5 & 1 & 10 & 2 & 4 \\
\hline$\underset{\sim}{\stackrel{D}{n}}$ & $\begin{array}{c}\text { Yaş grubu } \\
\text { içindeki yüzdesi }\end{array}$ & $\% 62,5$ & $\% 31,3$ & $\% 6,3$ & $\% 62,5$ & $\% 12,5$ & $\% 25$ \\
\hline & $\begin{array}{l}\text { Verilen cevap } \\
\text { içindeki yüzdesi }\end{array}$ & $\% 24,4$ & $\% 12,2$ & $\% 2,4$ & $\% 19,6$ & $\% 7,7$ & 8,5 \\
\hline & $\mathrm{n}$ & 17 & 5 & 7 & 9 & 8 & 12 \\
\hline$\stackrel{\infty}{D_{2}^{2}}$ & $\begin{array}{c}\text { Yaş grubu } \\
\text { içindeki yüzdesi }\end{array}$ & $\% 58,6$ & $\% 17,2$ & $\% 24,1$ & $\% 31$ & $\% 27,6$ & $\% 41,4$ \\
\hline$m$ & $\begin{array}{l}\text { Verilen cevap } \\
\text { içindeki yüzdesi }\end{array}$ & $\% 41,5$ & $\% 12,2$ & $\% 16,7$ & $\% 17,6$ & $\% 30,8$ & $\% 25,5$ \\
\hline & $\mathrm{n}$ & 7 & 17 & 18 & 19 & 11 & 12 \\
\hline$\underset{\sim}{\stackrel{\infty}{n}}$ & $\begin{array}{c}\text { Yaş grubu } \\
\text { içindeki yüzdesi }\end{array}$ & $\% 16,7$ & $\% 40,5$ & $\% 42,9$ & $\% 45,2$ & $\% 26,2$ & $\% 28,6$ \\
\hline$\nabla$ & $\begin{array}{l}\text { Verilen cevap } \\
\text { içindeki yüzdesi }\end{array}$ & $\% 17,1$ & $\% 41,5$ & $\% 42,9$ & $\% 37,3$ & $\% 42,3$ & $\% 25,5$ \\
\hline & $\mathrm{n}$ & 7 & 14 & 16 & 13 & 5 & 19 \\
\hline$\stackrel{\infty}{\pi}$ & $\begin{array}{c}\text { Yaş grubu } \\
\text { içindeki vüzdesi }\end{array}$ & $\% 18,9$ & $\% 37,8$ & $\% 43,2$ & $\% 35,1$ & $\% 13,5$ & $\% 51,4$ \\
\hline 10 & $\begin{array}{l}\text { Verilen cevap } \\
\text { içindeki yüzdesi }\end{array}$ & $\% 17,1$ & $\% 34,1$ & $\% 38,1$ & $\% 25,5$ & $\% 19,2$ & $\% 40,4$ \\
\hline & $\mathrm{n}$ & 41 & 41 & 42 & 51 & 26 & 47 \\
\hline$\stackrel{-1}{1}$ & $\begin{array}{c}\text { Yaş grubu } \\
\text { içindeki yüzdesi }\end{array}$ & $\% 33,1$ & $\% 33,1$ & $\% 33,9$ & $\% 41,1$ & $\% 21$ & $\% 37,9$ \\
\hline
\end{tabular}

Bulgular, 2 yaşındaki çocuklardan sadece birinin (\%6.3) olumsuz yalan söyleyebildiğini, \% 25’inin ise prososyal yalan söyleme davranışında bulunduklarını göstermektedir. Yine prososyal yalan söyleyip makul cevaplar vermeyen çocukların sayısının ise $4(\% 25)$ olduğu görülmektedir. Üç yaşındaki çocukların yalan söyleme becerilerine bakıldığında ise \%24.1'inin olumsuz yalan söyleme becerisi gösterdiklerini, \%41.4'ünün ise prososyal yalan söyleyip makul cevaplar verdikleri, hatta prososyal yalan söyleyen diğer gruptaki çocuklar da eklendiğinde bu oranın \%69'a ulaştığı sonucuna ulaşılmıştır. Dört yaşındaki çocukların yalan söyleme davranışları incelendiğinde, bu yaş grubundaki çocukların \%43'ünün olumsuz yalan, \%28.6’sının prososyal yalan söyleyebildikleri görülmüştür. Son olarak, 5 yaşındaki çocukların \%43.2'sinin olumsuz yalan söyledikleri, \%51.4'ünün de prososyal yalan söyledikleri bulunmuştur. Sonuçlar genel olarak değerlendirildiğinde, çalışmaya katılan çocukların \%34'ünün olumsuz yalan söyledikleri, \%33’ünün ise arkalarını döndükleri konusunda itirafta bulundukları sonucuna ulaşılmıştır. Prososyal yalan açısından değerlendirildiğinde, 
çocukların \%41’inin hediyeyi beğenmediğini söyleyerek beyaz yalana başvurmadığı görülmüştür. Prososyal yalan söyleyen çocukların ise \%38'inin makul cevaplarla beyaz yalanı sürdürdükleri bulunmuştur.

Çocukların yaşlarına göre olumsuz ve prososyal yalanları arasında anlamlı farklılık olup olmadığını test etmek için gerçekleştirilen ki-kare analizi sonucunda, ilk olarak olumsuz yalanların yaşa göre anlamlı farklılık gösterdiği bulunmuştur $[\chi 2(6)=25.12, \mathrm{p}<0.01]$. Tablo 2 incelendiğinde, 4 yaşındaki çocukların olumsuz yalan söyleme davranışlarının 2 ve 3 yaşındaki çocuklara kıyasla belirgin bir şekilde fazla olduğu ancak 4 ve 5 yaşındaki çocukların yalan söyleme davranışlarında çok fazla farklılık olmadığı görülmektedir. İki, 3, 4 ve 5 yaşındaki çocukların prososyal yalan söyleme davranışları arasında anlamlı farklılık olup olmadığını incelemek üzere gerçekleştirilen ki-kare analizi sonucunda ise yaşlar arasında anlamlı farklılıklar olmadığı bulunmuştur $[\chi 2(6)=9.2, \mathrm{p}>0.05]$. En büyük yaş grubu olan 60-72 aylık çocukların yarısında başkası yararına söylenen yalanlar (yalanı makul cevaplarla sürdürebilen grup) görülmekte, 4 yaş grubunda ise bu oranının düştüğü göze çarpmaktadır. Üç ve 4 yaşındaki çocuklanın prososyal yalan söyleyebilen çocukların kendi içerisindeki oranları her ne kadar eşit olsa da, her biri kendi yaş grubu içerisinde değerlendirildiğinde 3 yaşındaki çocukların prososyal yalanı daha fazla söyledikleri görülmektedir (Bkz. Tablo 2).

\section{SONUÇ ve TARTIŞMA}

Mevcut çalışmada, Türkiye'de yaşayan 2, 3, 4 ve 5 yaşındaki çocukların olumsuz ve prososyal yalan söyleyip söyleyemedikleri ve bu türdeki yalanların yaşa göre farklllık gösterip göstermediği incelenmiştir. Bulgular, çocukların yaşları ilerledikçe olumsuz yalanları daha fazla söyleyebildiklerini ancak söz konusu başkası yararına yalan olduğunda yaşlara göre anlamlı farklılık olmadığını göstermektedir.

Çalışmanın sonuç çıkarıcı analizlerini yorumlanmasına geçmeden, Türkiye'de yalan söyleme davranışının 4 yaşından küçük çocuklarda daha önce çalışılmamış olması nedeniyle bu duruma ilişkin bazı açıklamalar yapmak yerinde olacaktır. İlk olarak olumsuz yalan söyleme davranışı açısından değerlendirildiğinde, her ne kadar 2 yaş çocuklarının çoğunun arkalarını döndüklerinde itiraf ettikleri ya da arkalarını dönmeden bekledikleri görülse de, mevcut çalışmada yer alan 34 aylık bir çocuğun kural ihlalini gizlemesini gerektiren bir konuda yalan söyleme becerisini kazandığ1 bulunmuştur. Söz konusu bu durum, yurt dışında gerçekleştirilen birçok çalışma ile tutarlılık göstermektedir (Örn., Nagar, Williams ve Talwar, 2019; O’Connor ve Evans, 2018). Mevcut çalışmada kullanılan görevde, çocukların kural ihlalini gizlemeye yönelik olumsuz yalan söyleme davranışları incelenmiştir. Bu konuda birçok araştırmacı (Bkz. Ekman, 2016), çocukların 30 aydan 
itibaren basit sayılabilecek türden yalanları (hatasını ört bas etme, cezadan kaçınma gibi) söylemeye başladıklarını ifade etmiştir. Bu çalışma da, ülkemizde bu durumun benzerlik gösterdiği yönündeki bulgusuyla önceki çalışmaları destekler niteliktedir. Yine de, ülkemizde üç yaşından küçük çocuklarla böyle bir çalışmanın gerçekleştirilmemiş olması ve mevcut çalışmadaki 2-3 yaş arasındaki katılımcılarının sayısının yetersiz olması, 24-36 ay arasındaki çocuklardaki olumsuz yalan söyleme davranışlarının ne durumda olduğuna ilişkin soruları tam olarak aydınlatamamaktadır.

Çocukların prososyal yalan söyleme davranışlarına bakıldığında, olumsuz yalan söyleme davranışına kıyasla çocukların daha erken yaşta bu beceriyi gösterdikleri sonucuna ulaşılmıştır. Olumsuz yalan söyleme davranışına en küçük 34 aylık bir çocukta rastlanmasına karşın prososyal yalanın başlangıç olarak 32 aylık çocuklarda ortaya çıktığı ve 2 yaş grubundaki çocuklarda prososyal yalan söyleme oranının \%25 olduğu gözlenmiştir (Bkz. Tablo 2). Olumsuz yalanların yaşla birlikte arttı̆̆1 bulgusuna karşı prososyal yalan söyleme kendi içerisinde değerlendirildiğinde, yaşla birlikte belirgin bir doğrusal artışın olmadığı ve yaşça büyük çocukların da nezaket gerektiren bu durumda "hediyeyi beğenmedim" şeklinde doğru ifadelere başvurdukları göze çarpmaktadır. Aslında bu durum, yurt dışından gelen sonuçlarla tam olarak paralellik göstermemektedir. Prososyal yalanların 3 yaş civarında görüldügü (Örn., Talwar, Lavoie ve Crosssman, 2019) ve prososyal yalanlarda yaş farklılıkları olmadığ1 (Williams, Moore, Crossman ve Talwar, 2016) yönündeki bazı araştırma bulgularıyla uyumlu olduğundan söz edilebilir ancak özellikle Amerika ve Kanada gibi toplumlardan gelen sonuçlar olumsuz yalanların prososyal yalanlara kıyasla daha erken görüldüğüne işaret etmektedir (Ayrıntılı bilgi için bkz. Talwar ve Crossman, 2011).

Bu konuda yapılabilecek olası açıklamalardan biri, çocukların gelişimlerinin ilk dönemlerinde üzerinde en çok etkisi olan ebeveynlerin prososyal yalan konusunda da çocuklarını etkiliyor olabilecekleridir. Neredeyse bütün ebeveynlerin, çocuklarını yetiştirirken onun nasıl bir kişi olacağına, ahlaki değerlerinin, davranış standartlarının nasıl olacağına dair beklentileri bulunmaktadır. $\mathrm{Bu}$ nedenle sosyalleşme süreçlerinin içerisinde ebeveynlerin çocuklarının yalan söyleme davranışı üzerine etkileri olduğunu beklemek çok da yanlış olmayacaktır. Bizim toplumumuzda, nezaket gerektiren durum ve olaylarda halk dilinde küçük beyaz yalanlar söylenebileceği ya da her doğrunun her yerde söylenmesinin uygun olmayacağı şeklinde yaygın bir inanış olduğu bilinmektedir. Bu tür düşüncelere maruz kalan çocukların da buna uygun hareket ettikleri düşünülebilir. Okul öncesi dönemin ilerleyen yıllanında ise gelişen dil, bilişsel ve sosyal gelişime paralel olarak çocuklara ebeveynlerinin yanı sıra özellikle öğretmenleri tarafından kendi düşünce ve isteklerini rahatlıkla paylaşması konusunda desteklendirici eylemlerde bulunulması çocukların okul çağına doğru kendi isteklerine daha çok önem veriyor olabileceklerini akla getirebilir. Ancak, mevcut çalışmadan böyle bir yarg1ya ulaşmak mümkün olmadığ1 için yorum 
yaparken dikkat etmek gerekebilir. Türkiye'de daha önce bu tür bir çalışmanın yürütülmemiş olması bizim kültürümüzde ebeveynlik, okul, akran ve öğretmen etkisi gibi sosyalleşme faktörlerinin çocukların yalan söyleme davranışlarına etkisinin nasıl olduğuna dair yorum yapmayı zorlaştırmaktadır. Bu nedenle, bu konuda ileride yapılacak çalışmalar hem daha uygun bir fikre sahip olmamıza yardımcı olacak hem de alan yazına katkı sağlayacaktır.

Bulgular, yaşça büyük çocukların olumsuz ve prososyal yalan söyleme konusunda daha başarılı olduklarını göstermektedir. Bu durumun altında yatan nedene dair her ne kadar bu çalışmadan kesin bir sonuç çıkarmak mümkün olmasa da, bazı yorumlarda bulunulabilir. Çocukların yalan söyleyebilmesi için gerçek olan bilgiyi bastırabilmesi, başkalarının düşünce ve inançlarını değiştirebileceğini düşünmesi onların birtakım bilişsel beceriler bakımından belli bir düzeye ulaşmaları gerektiğini akla getirmektedir. Bu açıdan bakıldığında, çocuğun yalan söylemesi, doğruyu söylemesinden daha zorlu gibi görünmektedir. Bu nedenle, yalan söyleme davranışlarında yaşla birlikte bir artışın görülmesinde bilişsel becerilerin rolü olabilir.

Yalanın bir başkasının zihninde yanlış bir kanı yaratmayı gerektirdiğinden yola çıkılarak, yalan söyleme konusunda yapılan çalısmaların büyük bir kısmı, çocukların zihin kuramı becerilerinin yalan söyleme davranışları ile ilişkili olup olmadığını incelemiştir (Talwar ve Lee, 2002a; 2008). Örneğin, Polak ve Harris (1999), yanlış kanıları anlayabilen 3-5 yaş arasındaki çocukların, bu anlayışı henüz kazanamamış olan çocuklara göre bir kuralı çiğnediklerine bunu inkâr etme olasılıklarının daha fazla olduğunu bulmuşlardır. Farklı kanıları anlayabilme becerisinin, çocukların basit yalanlardan sıyrılarak daha karmaşık yalan söyleme becerilerini edinimlerinde rol oynadığı düşünülmektedir. Mevcut çalışmada edinilen bulgular da benzer bir şekilde, artan yaşla birlikte çocukların her iki yalan türünü söyleme konusunda daha başarılı olmalarının gelişmekte olan zihin kuramı becerilerinden kaynaklanabileceğini düşündürmektedir. Yine de, gelecekte yapılacak çalışmalarda zihin kuramı becerisi ile yalanın farklı türlerini Türkiye gibi farklı bir kültürde incelemek alan yazına katkı sağlayacaktır. Zihin kuramına benzer bir şekilde, yönetici işlevlerin de yalan söyleme becerisi için gerekli bir beceri olduğu ifade edilebilir. Yalanı başarılı bir şekilde söylemek ve sürdürebilmek için öncelikle doğru olan bilginin zihinde engellenmesi, doğru olmayan yeni bir bilginin üretilmesi ve söylenen yalanla ilgili bilgilerin gerçekle çelişmeyecek şekilde hatırlanması gerekmektedir (Gombos, 2006). Mevcut çalışmadan elde edilen sonuçlara göre, büyük çocukların olumsuz ve prososyal yalanları söyleme becerisinde daha iyi olmalarına bir neden olarak yönetici işlev becerileri gösterilebilir. Ancak çalışma kesin bir yorumda bulunabilmeyi mümkün kılmadığı için farklı yönetici işlev mekanizmalarının farklı yalan türleriyle bir arada ele alındığı araştırmaların hem ülkemizde hem de yurtdışında yapılmasına ihtiyaç duyulduğu söylenebilir. 
Yalan konusunda yürütülen çalışmaların birçoğu bilişsel faktörlere odaklanırken, sosyal ve/veya çevresel özelliklerin yalan söylemeyi nasıl etkilediği konusunda yapılan çalışmaların sınırlı olduğu göze çarpmaktadır. Çocukların ebeveynleri, akranları, öğretmenleri ve diğer kültürel etmenlerin aracılığıyla sosyalleştiği ve bunların çocukları çeşitli açılardan etkilediği bilinmektedir. Yalan davranışına izin verilmesi ya da yasaklanması, farklı kültürlerde farklı bağlamlara göre değişebileceği gibi çocukların yalan ve yalana ilişkin yargılarını da çeşitli şekillerde etkileyebilir. Hatta bazı durumlarda doğruyu söylemek bile bazı kültürde yanlış olarak değerlendirilirken, Kanada veya ABD gibi bireyciliğin ön planda olduğu ülkelerde yalanın çeşitli türlerine atfedilen değerler çok daha farklı olmaktadır (Bkz. Fu, Xu, Cameron, Heyman ve Lee, 2007; Lau ve diğerleri, 2013). Bu nedenle, bu çalışmada ortaya çıkan prososyal yalanın olumsuz yalanlara kıyasla daha erken görüldüğü bulgusu, sosyal ve kültürel etmenlerle de açıklanabilir. İki ile 3 yaş arasında prososyal yalanın daha fazla ortaya çıkması, bizim kültürel ve aile yapımızda başkalarına nezaket göstermenin kendi duygu ve düşüncelerimizi öncelemekten daha önemli görünmesinden kaynaklı olabilir. Bununla birlikte, Türkiye'nin bireyci-toplulukçu kültür konusunda çeşitli farklılıklar yaşadığı göz önünde bulundurulduğunda, ülkemizde yalan söyleme ve yalanı kabul edilebilir bulma gibi konularda gerçekleştirilecek çalışmaların yapılması faydalı olabilir.

Özetle, yalan çalışmalarında, hangi bilişsel becerilerin ve ailesel-sosyal faktörlerin etkili olup olmadığı gibi konulara odaklanılmıştır ancak ülkemizde bu tür değişkenlerle yalan söyleme davranışı arasındaki bağlantılar henüz incelenmemiştir. Bir diğer ifadeyle, çocuklarda yalan söyleme davranışı konusunda özellikle ülkemizde henüz cevaplanmayı bekleyen birçok problem olduğu yeterince açıktır. Bu nedenle, araştırmacıların gelecekte yapılacak çalışmalarda yalanın farklı türlerini çeşitli sosyal ve bilişsel faktörlerle birlikte incelemesi faydalı olabilir. Mevcut çalışmada yaşla birlikte yalan söyleme davranışlarının -özellikle olumsuz yalan- daha fazla görülmesi bilişsel becerilerin ve sosyalleşme süreçlerinin etkisi olabileceğini akla getirmektedir ancak bu yöndeki çıkarımların doğruluğunu gösterebilmek için çalışmalara ihtiyaç duyulmaktadır.

Çalışmanın önemli çıktılarından biri, olumsuz yalan söyleme davranışlarının okul öncesi dönemin sonlarına doğru arttığ1 şeklindeydi. Her ne kadar erken çocukluk döneminde söylenen yalanlar çok fazla problem teşkil etmiyorsa da, okula hazırlık dönemine doğru, eğitim kurumlarında dürüstlük değeri çeşitli yöntemlerle çocuklara anlatılarak yaşamın ilerleyen yıllarında bu türden antisosyal davranışların gelişimi azaltılabilir. Yalan söyleme ve dürüstlük üzerine gerçekleştirilecek eğitim programları aracilığıla kontrol ve deney gruplu yarı-deneysel desenli araştırmaların yürütülmesi hem eğitimcilere hem de alan yazına katkı sağlayacaktır. 
Bu çalışmanın birçok açıdan öncü olduğu rahatlıkla söylenebilir ancak bazı sınırlılıklarına değinmek gerekir. Çalışmanın katılımcıları, sadece İstanbul'da bulunan okul öncesi kurumlardan seçilmiştir. Bununla birlikte çocukların gelişimsel açıdan gerilik göstermemesi durumuna katılımcıların seçilmesinde dikkat edilmiştir. Bu nedenle, okul öncesi dönemdeki çocukların yalan söyleme becerilerine ilişkin edinilen bulguların gelişimi normal olan, aynı zamanda okul öncesi eğitimine devam eden çocuklarda ulaşıldığını söylemek gerekir. Ek olarak, sosyoekonomik düzeyi düşük anne-babalara sahip olmanın yanı sıra, küçük yaşlarda okula gitmemenin de, çocukların dil ve zihinsel gelişimleri açısından alacakları katkıyı sınırlandırabilir. Söz konusu bu durum, çocukların yalan söyleme becerilerine de etki edebilir. Ayrıca, çalışma grubundaki yaş dağılımlarının çok dengeli olmaması nedeniyle bazı karşılaştırmalar çok sağlıklı yapılamamıştır. Bu nedenle, farklı yerleşim yerlerinde yaşayan ve farklı sosyoekonomik düzeylerden oluşan ve yaş grupları açısından denk olacak bir katılımcı grubu üzerinde bu konunun araştırılması, hem çalışmanın genellenebilirliği artıracak hem de alan yazına katkı sağlayacaktır.

Sonuç olarak, 2 yaş kadar küçük çocukların yanı sıra 3, 4 ve 5 yaş çocukların olumsuz ve prososyal yalanlarının bir arada incelendiği bu çalışma ülkemizde okul öncesi dönemdeki çocukların yalan söyleme becerilerine ilişkin öncü araştırmalardan biri sayılabilir. Bu çalışmadan çıkan sonuç ise, olumsuz yalan söyleme becerilerinin yaşla birlikte belirgin bir artış gösterdiği, prososyal yalanın ise küçük yaşlardan itibaren daha yaygın olduğu şeklindedir. Çalışmanın büyük yaşlar lehine yalan söyleme becerisinin daha fazla olduğu yönündeki bulgusu, bundan sonraki çalışmalar için farklı bilişsel, sosyal ve duygusal gelişimsel faktörlerin yalan söyleme davranışlarıyla bağlantısını incelemenin gerekliliğini ortaya çıkarması bakımından önem taşımaktadır.

\section{KAYNAKÇA}

Aydın, M. Ş. (2020). Yalanın renkleri: Yalanın tanımlanması ve türleri üzerine bir değerlendirme. Uluslararası Sosyal Araștermalar Dergisi, 13(69), 1-9.

Cole, P. M. (1986). Children's spontaneous control of facial expression. Child Development, 57, 13091321.

DePaulo, B. M., Ansfield, M. E., Kirkendol, S. E., \& Boden, J. M. (2004). Serious lies. Basic and Applied Social Psychology, 26(2-3), 147-167.

DePaulo, B. M., Kashy, D. A., Kirkendol, S. E., Wyer, M. M., \& Epstein, J. A. (1996). Lying in everyday life. Journal of Personality and Social Psychology, 70, 979-995.

Ekman, P. (2016). Çocuklar Neden Yalan Söyler?. (Ç. Dirhemsiz, çev.) İstanbul: Yakamoz Yayınları.

Evans, A. D., \& Lee, K. (2013). Emergence of lying in very young children. Developmental Psychology, 49(10), 1958-1963. 
Fu, G., Xu, F., Cameron, C. A., Heyman, G., \& Lee, K. (2007). Cross-cultural differences in children's choices, categorizations, and evaluations of truths and lies. Developmental Psychology, 43(2), 278.

Gnepp, J., \& Hess, D. L. (1986). Children's understanding of verbal and facial display rules. Developmental Psychology, 22(1), 103-108.

Goffman, E. (1967). Interpersonal ritual: Essays on face-to-face behavior. New York: Pantheon Books.

Gombos, V. A. (2006). The cognition of deception: the role of executive processes in producing lies. Genetic, Social, and General Psychology Monographs, 132(3), 197-214.

Lau, Y. L., Cameron, C. A., Chieh, K. M., O’Leary, J., Fu, G., \& Lee, K. (2013). Cultural differences in moral justifications enhance understanding of Chinese and Canadian children's moral decisions. Journal of Cross-Cultural Psychology, 44(3), 461-477.

Lee, K., \& Ross, H. (1997). The concept of lying in adolescents and young adults: Testing Sweester's folkloristic model. Merrill-Palmer Quarterly, 43, 255 - 270.

Lewis, M. Sullivan, M. W., Stanger, C., \& Weiss, M. (1989). Self development and self-conscious emotions. Child Development, 60, 146-156.

Moll, H., \& Tomasello, M. (2007). How 14- and 18-month-olds know what others have experienced. Developmental Psychology, 43(2), 309-317.

Nagar, P. M., Williams, S., \& Talwar, V. (2019). The influence of an older sibling on preschoolers' lie-telling behavior. Social Development, 28(4), 1095-1110.

Newton, P., Reddy, V., \& Bull, R. (2000). Children's everyday deception and performance on falsebelief tasks. British Journal of Developmental Psychology, 18(2), 297-317.

O'Connor, A. M., \& Evans, A. D. (2018). The relation between having siblings and children's cheating and lie-telling behaviors. Journal of Experimental Child Psychology, 168, 49-60.

Oğuz, N., \& Kara, H. Ş. (2018). 54-66 aylık çocuklarda olumlu sosyal yalan davranışı ile zihin kuramı ve yönetici işlevlerin bağlantıları. Psikoloji Calısmalar, 38(2), 129-154.

Polak, A., \& Harris, P. L. (1999). Deception by young children following noncompliance. Developmental Psychology, 35, 561-568.

Saarni, C. (1984). An observational study of children's attempts to monitor their expressive behavior. Child Development, 55, 1504- 1513.

Talwar, V., \& Crossman, A. (2011). From little white lies to filthy liars: The evolution of honesty and deception in young children. In J. Benson (Ed.). Advances in child development and behavior (Vol. 40, pp. 139-179). Burlington: Academic Press.

Talwar, V., Lavoie, J., \& Crossman, A. M. (2019). Carving Pinocchio: Longitudinal examination of children's lying for different goals. Journal of Experimental Child Psychology, 181, 34-55.

Talwar, V., \& Lee, K. (2002a). Development of lying to conceal a transgression: Children's control of expressive behavior during verbal deception. International Journal of Behavioral Development, $26,436-444$.

Talwar, V., \& Lee, K. (2002b). Emergence of white-lie telling in children between 3 and 7 years of age. Merrill-Palmer Quarterly, 48, 160-181.

Talwar, V., \& Lee, K. (2008). Social and cognitive correlates of children's lying behavior. Child Development, 79(4), 866-881.

Talwar, V., Murphy, S. M., \& Lee, K. (2007). White lie-telling in children for politeness purposes. International Journal of Behavioral Development, 31(1), 1-11. 
Williams, S., Moore, K., Crossman, A. M., \& Talwar, V. (2016). The role of executive functions and theory of mind in children's prosocial lie-telling. Journal of Experimental Child Psychology, 141, 256-266.

Wilson, A. E., Smith, M. D., \& Ross, H. S. (2003). The nature and effects of young children's lies. Social Development, 12(1), 21-40. 